\title{
PERUBAHAN KEDUDUKAN PEREMPUAN PADA MASYARAKAT BATAK ANGKOLA
}

\author{
Helmi Suryana Siregar, Fatmariza Fatmariza \\ Universitas Negeri Padang, Sumatera Barat \\ helmiputrisiregar@gmail.com
}

\begin{abstract}
Abstrak
Penelitian bertujuan untuk mendeskripsikan kedudukan perempuan Batak Angkola dalam struktur adat Dalihan na Tolu dan perubahan kedudukan perempuan Batak Angkola Kontemporer. Penelitian ini dilakukan pada masyarakat Batak Angkola di daerah Pintu Padang. Informan yang adalah Tokoh Adat (hatobangon); Perempuan (anak perempuan, anak perempuan yang sudah nenikah, perempuan yang sudah memiliki menantu); Ulama dan Pakar adat setempat. Penelitian ini merupakan penelitian kualitatif dengan desain penelitian studi kasus yang menguji secara instensif terhadap suatu etnis tunggal yang dilengkapi dengan sumber dan objek yang diamati serta terbatas pada ruang dan waktu. Hasil dari penelitian menunjukkan bahwa perempuan menjadi objek sedangkan laki-laki menjadi subjek penentu kedudukan seseorang dalam struktur Dalihan na Tolu. Kedudukan perempuan pada masyarakat Batak Angkola dalam struktur adat Dalihan na Tolu ditentukan oleh kedudukan lakilaki baik sebagai ayah maupun sebagai suami. Perubahan kedudukan perempuan pada masyarakat Batak Angkola, disebabkan adanya pergeseran kebudayaan yaitu, status sosial, sistem mata pencaharian, sistem religi, dan pendidikan. Perubahan kedudukan perempuan pada masyarakat Batak Angkola bersifat positif, dimana munculnya kesadaran baik bagi kaum perempuan maupun lakilaki bahwa persamaan hak dan kewajiban perempuan. Hal ini ditandai dengan meningkatnya tingkat pendidikan kaum perempuan Batak Angkola, dan berhasil mengisi berbagai jenis pekerjaan yang selama ini hanya didominasi oleh kaum laki-laki.
\end{abstract}

Kata kunci : Kedudukan; Perempuan, Batak Angkola. 


\title{
CHANGES IN THE POSITION OF WOMEN IN THE BATAK ANGKOLA COMMUNITY
}

\begin{abstract}
The research aims to describe the position of Batak Angkola women in the traditional structure of the Dalihan na Tolu and the changes in the position of contemporary Batak Angkola women. This research was conducted on the Batak Angkola community in the Pintu Padang area. Informants who are traditional leaders (hatobangon); Women (daughters, married daughters, women who already have sons-in-law); Local customary scholars and experts. This research is a qualitative research with a case study research design that tests intensively against a single ethnicity equipped with sources and evidence of objects and objects observed and limited to space and time. The results of the study show bthat women become objects while men are the determining subjects of one's position in the Dalihan na Tolu structure. The position of women in the Batak Angkola community in the customary structure of Dalihan na Tolu is determined by the position of men both as fathers and as husbands. Changes in the position of women in the Batak Angkola community, due to a cultural shift, namely, social status, livelihood system, religious system, and education. Changes in the position of women in the Batak Angkola community are positive, where there is awareness for both women and men that women's equal rights and obligations. This is indicated by the increase in the education level of the Angkola Batak women, and the success of filling various types of jobs that have been dominated by men only.
\end{abstract}

Keywords: Position; Women, Batak Angkola. 


\section{PENDAHULUAN}

\section{A. Latar Belakang}

Suku Batak merupakan salah satu suku bangsa terbesar di Indonesia, nama ini merupakan sebuah tema kolektif untuk mengidentifikasikan beberapa suku bangsa yang bermukim dan berasal dari pantai barat dan pantai timur Sumatera Utara. Suku bangsa yang dikategorikan sebagai Batak adalah Toba, Karo, Pakpak, Simalungun, Mandailing dan Angkola. Suku Angkola atau sering juga disebut Batak Angkola adalah "salah satu sub-etnis dari suku Batak, tanah ulayat Batak Angkola berada diwilayah geografis Tapanuli Bagian Selatan”. Sistem kekerabatan masyarakat Batak Angkola yang disebut dengan Dalihan Na Tolu terdapat beberapa unsur yaitu unsur mora (orang tua istri), kahanggi (teman satu marga clan suami) dan anak boru (menantu laki-laki dan seluruh keluarganya). Dalihan Na Tolu ini adalah "adat yang sangat penting pada masyarakat Batak Angkola yang satu sama lain sangat erat dan tidak bisa dipisahkan sebab apaila hilang satu maka hilanglah sistem kekerabatan Batak Angkola". Dalihan Na Tolu yang memiliki peran dan mendukung dalam berperilaku pada semua aspek kehidupan, Dalihan Na Tolu menjadi kerangka hubungan-hubungan kerabat darah dan hubungan perkawinan yang mempertalikan suatu kelompok, dalam adat Batak.

Kedudukan atau posisi setiap orang dalam Dalihan Na Tolu ditentukan oleh laki-laki dan perempuan hanya sebagai pelengkap atau pendukung posisi laki-laki. Sesuai dengan penelitian Mangihut Siregar yang menjelaskan bahwa "perempuan menjadi kelompok inferior dan laki-laki sebagai kelompok superior". Kedudukan perempuan dalam Dalihan Na Tolu hanya sebagai objek sedangkan laki-laki menjadi subjek, dalam budaya Batak perempuan harus ikut keluarga laki-laki dan perempuan meninggalkan orang tua dan ikut keluarga suami". $\quad$ Pernyataan tersebut dipertegas oleh Nasrany Nainy Romaini dalam penelitiannya menjelaskan "kontradiksi sistem kekerabatan Dalihan Na Tolu

${ }^{1}$ Mangihut Siregar, “Ketidaksetaraan Gender Dalam Dalihan Na Tolu”, Jurnal Studi Kultural 3 (1), 2018, hal 13-14 
dengan kenyataan yang ditemukan perempuan menjadi subordinat dari laki-laki dan mengalami ketidakadilan perlakukan yang menghalangi perempuan tampil ke dunia publik". 2

Feminis Toril Moi menyatakan bahwa "sebuah posisi politik, perempuan adalah istilah biologis dan feminism adalah defenisis rangkaian karakter yang dibentuk oleh kebudayaan". Dengan kata lain seks secara umum digunakan untuk mengidentifikasi perbedaan laki-laki dan perempuan dari segi anatomi biologi. Artinya, "istilah tersebut lebih banyak berkonsentrasi pada aspek biologi seseorang, meliputi perbedaan komposisi kimia dan hormon dalam tubuh, anatomi fisik, reproduksi, dan karakteristik biologis lainnya. Sedangkan istilah gender lebih berkonsentrasi kepada aspek sosial budaya, psikologis, dan aspekaspek non biologis lainnya". 3

Tidak banyak penelitian sebelumnya yang mengangkat penelitian tentang kedudukan perempuan batak, penelitian sebelumnya oleh Helprida Nababan (2017) hanya meneliti tentang bagaimana kedudukan anak perempuan mengenai hak waris masyarakat Batak yang menetap di Kota Pontianak. Penelitian tersebut juga meneliti tentang faktor-faktor apa saja yang sesungguhnya mempengaruhi perubahan kedudukan anak perempuan dalam hukum waris adat pada masyarakat Batak Toba yang sudah hidup merantau di Kota Pontianak. Penelitian tersebut menjelaskan tentang kedudukan anak perempuan dan anakanak laki-laki mempunyai hak dan pembagian waris yang sama, hal tersebut masih belum berlaku di daerah asalnya yang masih menggunakan warisan secara turun menurun hanya dibagikan kepada anak laki-laki. ${ }^{4}$ Penelitian ini hanya meneliti tentang kedudukan anak perempuan Batak dalam pembagian waris yang hidup di perantauan yaitu di Kota Pontianak.

\footnotetext{
2 Nasrany Nainy Romaini, "Posisi Perempuan Dalam Adat Dan Kebudayaan Masyarakat Batak Toba" Skripsi, hal 13-14. 1985.

3 Toril Moi, "Sexual/Textual Politics: Feminist Literary Theory". London; New York: Methuen,

${ }^{4}$ Helprida Nababan, “Kedudukan Anak Perempuan Pada Masyrakat Batak Toba Dalam Hukum Waris Adat Di Kota Pontianak”, Jurnal Gloria Yuris 5 (3), 2017.
} 
Penelitian oleh Rouli Lastiurma Sinaga (2017) yang berjudul “ Kedudukan Anak Perempuan Dalam Hukum Waris Adat Pada Masyarakat Batak Di Kabupaten Aceh Tengah". Penelitian tersebut lebih banyak mengkaji tentang kedudukan anak perempuan masyarakat Batak yang menetap di Aceh Tengah. Permasalahan selanjutnya yang diteliti adalah faktor-faktor yang mempengaruhi perubahan kedudukan perempuan dalam pembagian hak waris. Masyarakat Batak yang merantau di Aceh Tengah dalam membagikan waris sudah tidak membedakan lagi baik itu waris untuk anak laki-laki maupun untuk anak perempuan. Banyak faktor yang menyebabkan perubahan pembagian hak waris bagi masyarakat Batak yang tinggal di Kabupaten Aceh Tengah ini antara lain faktor agama, faktor ekonomi, faktor lingkungan dan faktor perkawinan. $^{5}$

Perbedaaan penelitian ini dengan penelitian sebelumnya terkait dengan kedudukan perempuan dalam mayarakat Batak adalah penelitian ini mempunyai kebaharuan dengan meneliti secara khusus tentang kedudukan perempuan di masyarakat Batak Angkola. Melalui penelitian ini akan dikaji apakah perempuan di Batak Angkola tidak bisa menentukan kedudukannya sendiri, kedudukan perempuan sangat tergantung pada laki-laki yang mendampinginya, yang bertugas untuk melindunginya. Dimana ketika kedudukan laki-laki itu kuat maka kedudukan perempuan akan menjadi kuat juga, artinya dalam masyarakat Batak Angkola perempuan itu kurang memiliki otoritas terhadap dirinya sendiri, adanya ketidakadilan gender yang berpengaruh terhadap kedudukan laki-laki dan perempuan ternyata terkontaminasi dengan budaya. Penelitian bertujuan untuk mendeskripsikan kedudukan perempuan Batak Angkola dalam struktur adat Dalihan na Tolu dan perubahan kedudukan perempuan Batak Angkola Kontemporer.

5 Rouli Lastiurma Sinaga, “ Kedudukan Anak Perempuan Dalam Hukum Waris Adat Pada Masyrakat Batak Di Kabupaten Aceh Tengah”, JIM Bidang Hukum Keperdataan 1 (1), 2017, hal 185-194. 


\section{B. Permasalahan}

Apakah pelanggaran ketidakadilan gender terhadap kedudukan antara lakilaki dan perempuan secara general memang berasal dari pemahaman, penafsiran dan pemikiran yang dipengaruhi oleh tradisi atau kultur partriarki dan sistem kekerabatan Dalihan Na Tolu pada masyarakat Batak Angkola?

\section{Metode Penelitian}

Penelitian ini merupakan "penelitian kualitatif dengan desain penelitian studi kasus yang menguji secara instensif terhadap suatu etnis tunggal yang dilegkapi dengan sumber dan bukti objek yang diamati serta terbatas pada ruang dan waktu". Penelitian ini bertujuan untuk mendapatkan gambaran atau pengetahuan yang mendalam mengenai peristiwa sesuai dengan konteksnya. ${ }^{6}$

Penelitian ini dilakukan pada masyarakat Batak Angkola di daerah Pintu Padang. Lokasi ini dipilih karena masyarakatnya heterogen dan makin tingginya minat perempuan di Pintu Padang untuk memperoleh pendidikan yang tinggi serta makin banyaknya perempuan yang bekerja di luar rumah tapi tetap menjunjung adat istiadat yang sudah ada sejak dulu, oleh karena hal itu maka peneliti memilih daerah Pintu Padang sesuai dan bisa mewakili daerah lainnya tentang permasalahan kedudukan perempuan pada masyarakat Batang Angkola. Narasumber penelitian ini berasal dari tokoh adat (hatobangon); perempuan (anak perempuan, perepmpuan yang sudah menikah, perempuan yang sudah memiliki menantu); ulama dan pakar adat.

Teknik pengumpulan data dalam penelitian ini dengan, (1) "Observasi, dimana digunakan observasi secara langsung dan secara tidak langsung dan.” (2) "Wawancara mendalam, dilakukan dengan informan dengan melakukan wawancara secara mendalam dengan menanyakan atau mengklarifikasi informasi yang sudah didapatkan dalam wawancara sebelumnya kepada informan yang sama dengan tujuan agar lebih mendalami lagi informasi yang telah didapatkan".

6 Tohirin, "Metode Penelitian Kualitatif dalam Pendidikan dan Bimbingan Konseling”, (Jakarta: Rajawali Pers, 2012), hlm. 19-21. 
Analisis data dalam penelitian ini dilakukan dalam dua tahap, yaitu analisis ketika di lapangan dan analisis pasca lapangan. Analisis ketika di lapangan dilakukan untuk menemukan kesimpulan sementara untuk kemudian dilakukan penelitian kembali dan seterusnya. Adapun analisis pasca lapangan dilakukan dengan menelaah seluruh data yang telah diperoleh dari lapangan untuk kemudian didapatkan hasil dalam bentuk laporan. Tekhnik analisis data model interaktif menurut Miles dan Hiberman digunakan dalam penelitian ini. ${ }^{7}$ Yang dilaksanakan dengan "aktifitas dalam analisis data kualitatif dilakukan secara interaktif dan dilakukan secara terus menerus sampai tuntas sehingga datanya sudah jenuh yaitu data reduction, data display, conclusion drawing/verification".

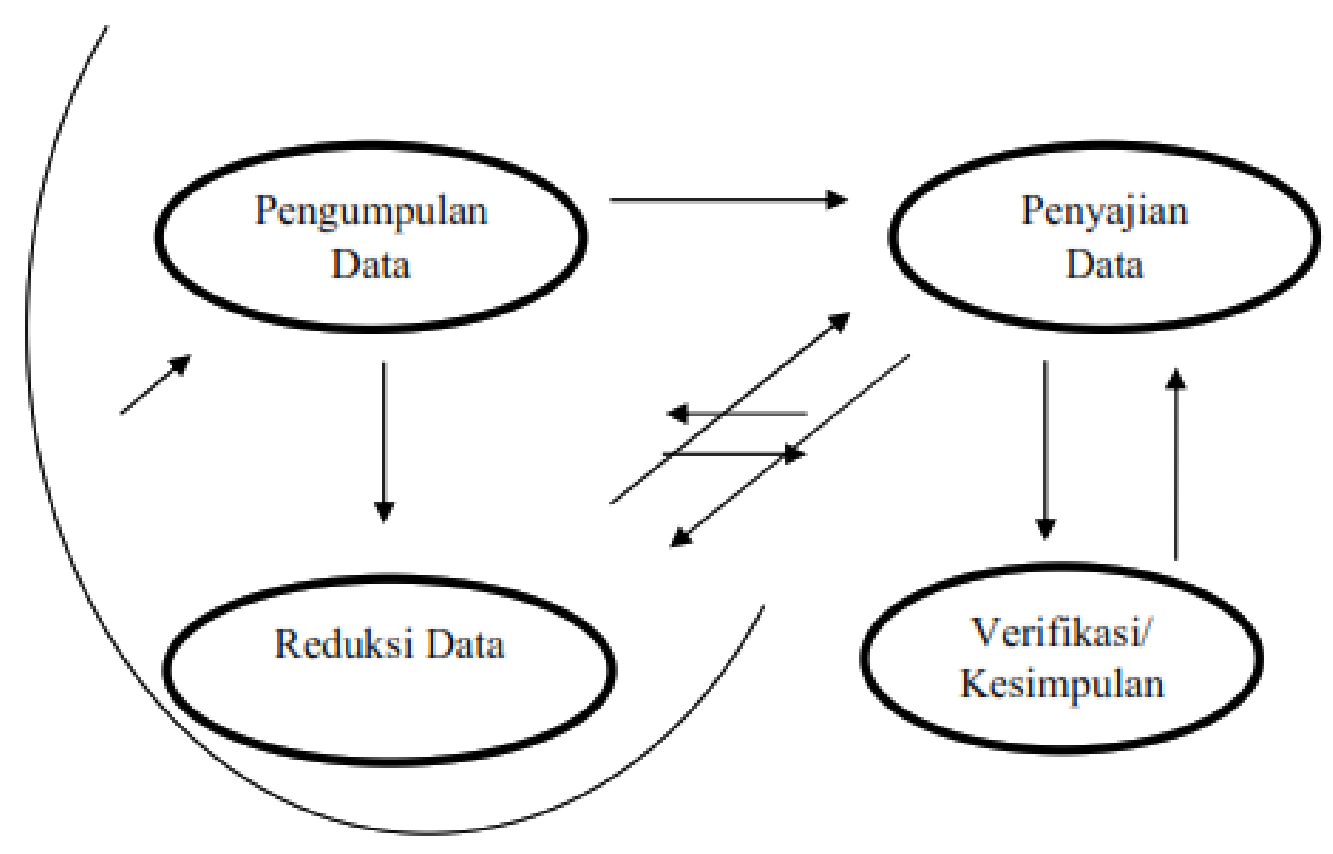

Gambar.1 Analisis Data Interaktif

7 Ibid. 


\section{PEMBAHASAN}

Christina S.Handayani dan Novianto Ardhian dalam Indah Ahdiah juga menyatakan "asal kata perempuan adalah empu yang bermakna dipertuan atau dihormati". Perubahan penggunaan kata wanita menjadi perempuan dianggap simbolisasi perempuan yang semula diposisikan sebagai objek menjadi subjek. 8 Tri Marhaeni \& Pudji Astuti juga mengatakan bahwa "perempuan identik dengan alam yang dikuasai manusia". Dari analogi alam adalah "benda barang lahan yang dikuasai dan dieksplorasi manusia, bahkan dieksploitasi”. Dengan demikian implikasi dari analogi perempuan dengan alam maka perempuan juga “menjadi yang dikuasai" oleh manusia lain (manusia masyarakat laki-laki). ${ }^{9}$

Jadi dari uraian diatas disimpulkan bawah perempuan adalah mahluk terhormat yang memiliki kebebasan untuk memilih dan membuat keputusan baik untuk pribadinya maupun lingkungannya, walaupun adanya perbedaan biologis antara antara laki-laki dan perempuan. Perempuan merupakan penyangga sebuah bangunan agar berdiri dengan kokoh begitu juga dalam kehidupan berkeluarga dan masyarakat perempuan adalah ujung tombaknya.

Di masyarakat Batak pada umumnya perempuan sering di nomor duakan dan masing sering terjadi diskriminasi terhadap perempuan. Mengingat masyrakat Batak itu sendiri masih menganut system patriarki, sehingga posisi dominan masih banyak dipegang oleh laki-laki. Saat ini di masyarakat Batak sudah terjadi pergeseran dan perubahan terkait dengan peranan dan kedudukan perempuan. Perempuan di masa ini sudah banyak bekerja di luar rumah bahkan menjadi penopang utama perekonomian keluarga. ${ }^{10}$

Kedudukan dan peranan perempuan di Minangkabau nerneda dengan masyarakat Batak. Kedudukan perempuan di Minangkabau mempunyai

\footnotetext{
${ }^{8}$ Indah Ahdiah, "Peran-Peran Perempuan Dalam Masyarakat", Jurnal Academica 5 (2), 2013.

${ }^{9}$ Pudji Astuti, Tri Marhaeni, “Ekofeminisme Dan Peran Perempuan Dalam Lingkungan”, Indonesian Journal of Conservation 1 (1), 2012.

${ }^{10}$ Grecetinovitria Merliana Butar-Butar, "Eksistensi Perempuan Batak Toba Dalam Budaya Dan Agama”, Jurnal Pionir LPPM Universitas Asahan 6 (2), 2020, hal 190-202.

DOI : $10.36294 /$ pionir.v6i2.1235
} 
kedudukan yang istimewa. Perempuan yang dalam istilah Minangkabau dikenal dengan padusi. Perempuan atau padusi mempunyai peran yang istimewa karena hampir dalam pengambilan keputusan ada di tangan perempuan. Suatu rencana atau keputusan belum dapat dilaksnakan jika belum mendapat persetujuan dari perempuan. Di Minangkabau perempuan juga disebut sebagai bundo kanduang yang secara harfiah dapat disebut sebagai ibu kandung. ${ }^{11}$

Peranan Dalihan Na Tolu ini merupakan suatu hal yang tidak dapat dipisahkan dalam kehidupan bermasyarakat di dalam masyarakat Dalam suatu perkawinan yang sah, Dalihan Na Tolu telah menggariskan dan menetapkan aturan dan ketentuan rinci mengenai berbagai hubungan sosial baik antara suami dengan istri, antara orang tua dengan saudara-saudara kandung dari masingmasing pihak pengantin, maupun dengan anak boru serta mora dari masingmasing pihak". ${ }^{12}$ Perkawinan Batak itu merupakan pranata yang menghubungkan tiga kelompok clan. Sebetulnya clan disini lebih tepat diartikan sebagai lineage (Koentjaraningrat menyebutnya clan kecil), atau orang-orang yang sa-ompu (satu kakek moyang bersama, biasanya sampai 3-5 generasi), yang masih dapat diidentifikasi dengan jelas garis keturunannya, clan kecil ini berada dalam satu kelompok kekerabatan besar yang dikenal dengan istilah marga. ${ }^{13}$ Clan kecil penerima perempuan (ayah dari pengantin laki-laki) disebut anak boru, clan kecil (ayah) yang memberi anak perempuan disebut mora; sedangkan clan kecil sesama warga suatu kelompok kekerabatan (dihitung berdasarkan garis laki-laki) disebut Kahanggi.

Dari uraian diatas bisa kita disimpulkan Dalihan $\mathrm{Na}$ Tolu dalam perkawinan merupakan struktur kultural yang mewujudkan seperangkat aturanaturan, pandangan hidup, niali-nilai, atau prinsip-prinsip tertentu yang mendasarinya dan hidup dalam kebudayaan pada masyarakat. Dalihan Na Tolu

\footnotetext{
${ }^{11}$ Silvi Novita Nurman, “Kedudukan Perempuan Minangkabau Dalam Perspektif Gender”, Jurnal Al-Aqidah 11 (1), 2019, hal 94. DOI : 10.15548/ja.v11i1.911

12 Eric Evonsus Simbolon dkk (2017), "Peranan Dalihan Natolu Dalam Hukum Perkawinan Adat Batak Toba”, Pactum Law Journal Vol 1 No. 12017.

13 Rismawati Rismawati, "Perkawinan Dan Pertukaran Batak Toba (Sebuah Tinjauan Strukturalisme Antropologi)”, Jurnal Academica 3 (2), 2011.
} 
berfungsi menentukan tentang kedudukan, hak dan kewajiban seseorang atau kelompok orang atau mengatur dan mengendalikan tingkah laku seseorang atau kelompok dalam kehidupan adat bermasyarakat. Selain itu juga berfungsi sebagai dasar dalam bermusyawarah dan mufakat masyarakat Batak Angkola.

Sistem kekeluargaan yang dikenal pada masyarakat Batak Toba adalah sistem patrilineal, yang berdasarkan garis keturunan laki-laki dan merupakan generasi penerus orang tuanya sedangkan anak perempuan bukan generasi orang tuanya. Akibat dari sistem ini sangat berpengaruh terhadap kedudukan anak perempuan di dalam hal warisan TAP MPRS No. II Tahun 1960 dan putusan Mahkamah Agung No. 179 K/Sip/1961 merupakan perkembangan terhadap kedudukan anak perempuan sebagai ahli waris orang tuanya.

Dalihan Na Tolu (Tungku yang Tiga), merupakan basic structure dari masyarakat Batak. Makna yang tersirat dari "Dalihan Na Tolu" ini adalah merupakan sturktur kekerabatan masyarakat Batak, yang merupakan simbol hubungan kekerabatan masyarakat Batak secara umum dan Batak Angkola khususnya. Kekerabatan yang tertuang dalam Dalihan $\mathrm{Na}$ Tolu meliputi Kahanggi, Mora, Anak Boru. Munculnya hubungan Dalihan Na Tolu dalam satu anggota masyarakat disebabkan adanya pertalian darah, baik hasil dari hubungan perkawinan maupun hubungan antar semarga.

Berdasarkan hasil pengumpulan dan penafsiran data penelitian dilapangan, struktur adat Dalihan $\mathrm{Na}$ Tolu terdapat tiga unsur yang saling berkaitan, yaitu kahanggi (semarga), anak boru (pihak yg menikahi saudara perempuan), dan mora (pihak pemberi istri). Dalihan Na Tolu menjadi tolak ukur sistem kekerabatan Batak, sehingga tutur ditentukan oleh posisi seseorang dalam Dalihan Na Tolu. Istilah perempuan dalam adat Batak Angkola disebut sebagai boru. Perempuan menjadi indikator kedudukan seorang laki-laki dalam struktur adat Dalihan Na Tolu yaitu: mora (pemberi boru, ayah dari istri, saudara lakilaki istri, saudara laki-laki ibu) dan harus dihormati. Dan biasanya disebut sebagai boru ni raja, karena keluarga pemberi istri merupakan raja bagi setiap laki-laki Batak. 
Perempuan Batak biasa disebut dengan panggilan puteri raja, sehingga perempuan Batak mendapat pengawasan yang sangat kaku. Sebab akan menentukan kedudukan laki-laki dalam masyarakat Batak. Perempuan Batak sejak beranjak remaja dibimbing oleh ibu (parsonduk bolon) bagaimana menjadi istri yang baik, seperti taat kepada suami, dan keluarganya, sampai terbentuk prilaku boru ni raja agar bisa memberikan kehormatan kepada ayah dan saudara laki-laki. seorang perempuan sekali ia menikah, ada tiga kedudukan yang dimilikinya yaitu, sebagai parsonduk bolon, ibu kedua bagi adik suaminya, paniaran (ibu bagi komunitas marga. Sedemikian berartinya perempuan bagi masyarakat adat Batak hingga orangtua yang paham adat dan tata krama adat Dalihan na tolu, jauh-jauh hari sudah menyiapkan anak gadisnya agar bisa mendekati standar perilaku yang dianggap ideal yang disebut 'boru ni raja'.

Agama Islam banyak membawa pengaruh besar terhadap sistem nilai adat dalihan Na Tolu. Tradisi yang melanggar hukum Islam menjadi melonggar, hal ini tidak terlepas dari ketaatan masyarakat Batak Angkola yang lebih mengutamakan aturan dalam Agama Islam daripada adat. Sehingga banyak tradisi yang mengalami penyesuaian dengan Islam. Perubahan itu seperti, tradisi mangupa yang pada awalnya menggunakan daging babi dirubah menjadi daging kambing. Hal serupa juga dapat ditemukan pada upacara siluluton (duka) pada awalnya yang melakukan tradisi manortor siluluton (tarian kematian sambil menangis) hal ini juga ditinggalkan dan diganti dengan tahlilan.

Interaksi adat Daliha $\mathrm{Na}$ Tolu dengan Islam juga ditemukan pada kedudukan perempuan pada Masyarakat Batak Angkola. Perempuan menjadi inferior dalam tatanan kehidupan masyarakat Batak mengalami pergeseran secara signifikan sesuai dengan nilai-nilai syariat Islam. Konsep adat Dalihan Na Tolu sebagai sistem sosial masyarakat yang menyangkut kekerabatan dalam menjalankan segala aktivitas yang bertalian dengan adat. Konsep adat Dalihan $\mathrm{Na}$ Tolu bersendikan nilai-nilai Islam, sehingga terbentuk keharmonisan adat Dalihan Na Tolu dan agama Islam pada masyarakat Batak Angkola.

Kedudukan perempuan dalam adat Dalihan $\mathrm{Na}$ Tolu, seiring dengan perkembangan zaman, inferior perempuan mulai mengalami perubahan hal ini 
ditandai dengan terjadinya pergeseran kebudayaan. Berdasarkan hasil observasi yang dilakukan peneliti dibeberapa tempat di Tapanuli Selatan, ada beberapa bentuk pergeseran kebudayaan yang mendorong perubahan kedudukan perempuan Batak yaitu: status sosial, sistem mata pencaharian, sistem religi, dan pendidikan.

Saat ini masyarakat Angkola masih mempedomani budaya leluhur dalam mempersiapkan anak-anaknya. Akan tetapi keutaman anak laki-laki dalam keluarga sudah berubah hal ini tidak terlepas dari kesadaran masyarakat Angkola terhadap peran perempuan masa kini yang sudah banyak menempati posisi lakilaki. Pada awalnya masyarakat Angkola memang mempercayai bahwa keutamaan dan kewibawaan ada pada anak laki-laki, tapi banyak masyarakat melihat fakta justru sekarang perempuan yang lebih tulus kepada orang tuanya. Sehingga kesetaraan perempuan dalam keluarga Angkola juga sama dengan laki-laki khususnya pada aspek pendidikan, banyak keluarga Angkola yang saat ini juga mempersiapkan anak perempuannya sama seperti mempersiapkan anak laki-lakinya.

Namun demikian ada hal-hal yang masih dipertahankan hingga saat ini terkait dengan keutamaan anak laki-laki dalam keluarga, seperti pembagian harta warisan, telah ada perubahan kedudukan dalam persiapan masa depan anak perempuan, akan tetapi pembagian harta warisan masih tetap mempertahankan aturan adat. Hal ini disebabkan adanya kepercayaan bahwa simbol eksitensi garis keturunan masih setara dengan symbol kepemilikan harta. Simbol marga melekat pada harta, sebuah rumah, kebun, sawah atau apapun yang sifatnya kebendaan dikenali dengan laki-laki yang memilikinya. Rumah misalnya, sekalipun perempuan yang memilikinya secara hukum Negara, akan tetapi masyarakat Angkola masih melihat itu dari marga suaminya artinya rumah itupun punya marga, dan marga hanya miliki laki-laki.

Adventi Ferawati Sembiring (2018) pada penelitiannya menyampaikan bahwa ada beberapa faktor yang mempengaruhi kedudukan perempuan Batak Karo. Perubahan kedudukan perempuan Batak Karo tentang warisan dimana anak laki-laki dan perempuan Batak Karo mempunyai kedudukan yang sama 
dalam pembagian warisan. Perubahan kedudukan ini disebabkan faktor pendidikan, aktor perantauan, faktor agama dan faktor sosial. ${ }^{14}$ Perubahan kedudukan perempuan antara Batak Karo dan Batak Angkola juga mempunyai perbedaan.

Penelitian Harisan Boni Firmando yang meneliti tentan perempuan Batak Karo di Tapanuli Utara juga menjelaskan bhwa perempuan Batak Karo mempunyai peranan yang penting. Di Batak Karto peranan perempuan disimbolkan berupa rumah tradisional Batak Toba yang mempunyai empat payudara. Adanya ukiran berupa cicak pada rumah tradisional Batak Toba yang mengahadap ukiran empat payudara yang di Batak Karo dikenal sebagai adop-adop. Keempat adop-adop ini masing masing mempunyai makna dan arti. Adop-adop yang pertama sebagai "simbol kesucian", adop-adop yang kedua sebagai "simbol kesetiaan". Adop-adop yang ketiga sebagai "simbol kesejahteraan", serta adop-adop yang keempat sebagai "simbol kesuburan wanita". Lebih lanjut bagi masyarakat Batak Toba, payudara melambangkan wanita dan kesuburan, yang berasal dari ibu. Artinya, masyarakat batak yang merantau, di manapun berada harus kembali kepada tanah kelahirannya. ${ }^{15}$

Pergeseran kedudukan perempuan yang sudah menikah dapat ditinjau dari segi kepemimpinan dan keanggotaan baik dalam kelompok kekerabatan yang terkecil (keluarga menek), maupun kelompok kekerabatan besar (keluarga godang). Keluarga menek ini terdiri dari suami, istri, dan anak-anak; belum menikah atau dapat disebut keluarga inti yang sederhana. Dalam hal ini, dilihat dari masa lampau kedudukan perempuan yang sudah menikah dalam keluarga hanya pada status sebagai anggota dan tidak memiliki hak untuk memutuskan sesuatu hal bagi keluarga. Akan tetapi hal tersebut mulai bergeser, dimana

${ }^{14}$ Adventi Ferawati Sembiring, "Kedudukan Perempuan Dalam Hukum Waris Adat Pada Sistem Kekerabatan Patrilineal Di Lau Pakam, Kecamatan Mardingding, Kabupaten Karo, Provinsi Sumatra Utara”, Jurnal Hukum Dan Dinamika Masyarakat 15 (2), 2018, hal 102-109.

DOI : $\underline{10.36356 / \text { hdm.v15i2.679 }}$

${ }^{15}$ Harisan Boni Firmando, "Status dan Peranan Perempuan Setelah Berumah Tangga dalam Masyarakat Batak Toba di Tapanuli Utara (Analisis Sosiologis) Status and Role of Women After Married at Toba Batak Community in North Tapanuli (Sociological Analysis)', Jurnal Intervensi Sosial dan Pembangunan 2 (1), 2021, hal 23-38. 
seorang istri dalam keluarga kecil pada masa sekarang ini dapat memutukan sesuatu untuk keluarga menek. Sebab, istri dapat berperan ganda sebagai ibu dan juga pemimpin rumah tangga. Hal tersebut dipicu pula oleh adanya kemampuan seorang perempuan yang dapat melakukan aktivitas ekonomi.

Tidak hanya pada lingkup keluarga menek, pada keluarga yang lebih luas kedudukan dan peranan perempuan Angkola juga mengalami pergeseran. Dimana seorang perempuan awalnya hanya sebagai pelengkap dalam kegiatan rumah tangga dan upacara-upacara adat. Akan tetapi, pada masa sekarang perempuan Angkola memiliki peran dan kedudukan yang jauh lebih penting dari laki-laki. Perempuan Angkola dapat menjadi penentu dan memberi keputusan atas berbagai kegiatan keluarga luas serta menjadi tokoh penting dalam upacaraupacara adat. Perempuan dianggap paling mengerti dan memahami mengenai tata cara upacara maupun materi dari upacara.

Pada sistem sosial masyarakat Angkola, bagi perempuan yang telah menikah mutlak harus mengikuti kehendak kerabat laki-laki. Dalam hal ini yang dimaksudkan adalah hukum adat menetap setelah menikah. Seorang perempuan harus mengikuti adat virilokal, yang menentukan bahwa pengantin baru menetap sekitar tempat kediaman kaum kerabat suami (laki-laki). Pada masa sekarang ini, adat setelah menikah yang dianut oleh masyarakat Angkola ini masih dilaksanakan. Meski begitu, adat menetap ini telah mengalami pergeseran. Seorang perempuan Angkola pada masa ini, dapat memilih tempat tinggal yang baru dengan tidak mengelompok pada kediaman kerabat suaminya. Terdapat kecenderungan bahwa adat menetap virilokal berganti menjadi adat menetap neolokal. Hal ini merupakan hasil dari adanya kedudukan dan majunya pendidikan yang perempuan Angkola peroleh dan pendapatan ekonomi mereka yang tidak dapat diremehkan.

Pergeseran status sosial pada kedudukan perempuan Angkola, terdapat beberapa unsur penting pembentuk hubungan sosial yang dapat dikaji untuk memperoleh data guna memahami mengenai pergeseran kedudukan dan peran perempuan khususnya yang sudah janda. Perempuan yang sudah janda dalam budaya Angkola ada dua kategori yaitu, (1). Marando (perempuan cerai hidup) 
dan (2). Mabalu (perempuan cerai mati. kedudukan perempuan yang dicerai dalam masyarakat Angkola masih terpinggirkan dengan status social yang diaggap jelek. Sekalipun sudah ada kesadaran perempuan maupun orang tuanya terhadap hak-haknya sebagai manusia. Akan tetapi struktur adat Angkola masih mempertahankan budaya Angkola kuno, perempuan tidak memiliki hak apapun terhadap harta dan anak-anaknya apabila telah diceraikan oleh suaminya.

Kesadaran perempuan janda terhadap penindasan yang dialaminya, tidak terlepas dari status social dan jenjang pendidikannya. Perempuan dengan status mabalu adalah perempuan yang ditinggal mati suaminya. Perempuan yang ditinggal mati suaminya dalam aturan adat tetap menjadi milik keluarga almarhum suaminya terlebih sudah memiliki anak. Akan tetapi kedudukannya hanyalah sebagai ibu bagi anak-anaknya, dan tetap dapat menggunakan harta suami untuknya. Perempuan dengan cerai mati tetap memiliki kedudukan yang sama seperti ibu mertuanya dengan ketentuan apabila telah memiliki anak. Akan tetapi perempuan yang tidak memiliki anak dipulangkan kembali kepada orang tuanya. Dan dia kembali seperti anak perempuan yang belum menikah dan kembali menjadi tanggung jawab ayahnya, apabila ayahnya sudah tidak ada maka dia menjadi tanggung jawab saudara laki-lakinya.

Sekalipun perempuan yang dicerai mati suaminya, tetap memiliki kedudukan yang sama dengan ibu mertuanya, akan tetapi apabila dia menikah dengan laki-laki lain yang bukan saudara kandung suaminya maka seluruh harta dan anak-anaknya akan ditarik oleh keluarga suaminya.

\section{PENUTUP}

Perempuan dalam adat Batak Angkola disebut sebagai boru. Perempuan menjadi indicator kedudukan seorang laki-laki dalam struktur adat Dalihan $\mathrm{Na}$ Tolu yaitu: mora (pemberi boru, ayah dari istri, saudara laki-laki istri, saudara laki-laki ibu) dan harus dihormati. Dan biasanya disebut sebagai boru ni raja, karena keluarga pemberi istri merupakan raja bagi setiap laki-laki Batak.Kedudukan perempuan pada masyarakat Batak Angkola dalam struktur adat Dalihan Na Tolu ditentukan oleh kedudukan laki-laki baik sebagai ayah maupun sebagai suami. Kedudukan perempuan dalam struktur adat Dalihan na 
Tolu, tidak nampak secara jelas yang paling dominan adalah laki-laki, sedangkan perempuan hanyalah sebagai alat ukur untuk menentukan seseorang apakah berposisi sebagai mora atau anak boru. Perubahan kedudukan perempuan pada masyarakat Batak Angkola, disebabkan adanya pergeseran kebudayaan yaitu, status sosial, sistem mata pencaharian, sistem religi, dan pendidikan. Perubahan kedudukan perempuan pada masyarakat Batak Angkola bersifat positif, dimana munculnya kesadaran baik bagi kaum perempuan maupun laki-laki bahwa persamaan hak dan kewajiban perempuan. Hal ini ditandai dengan meningkatnya tingkat pendidikan kaum perempuan Batak Angkola, dan berhasil mengisi berbagai jenis pekerjaan yang selama ini hanya didominasi oleh kaum laki-laki.

\section{DAFTAR PUSTAKA}

\section{Buku}

Matthew Miles, Huberman B, and Saldana, Jhony, "Qualitative Data Analysis A Methods Sourcebook", Singapore: SAGE Publications, 2014

Tohirin, "Metode Penelitian Kualitatif dalam Pendidikan dan Bimbingan Konseling”, Jakarta, Rajawali Pers, 2012.

Toril Moi, "Sexual/Textual Politics: Feminist Literary Theory", London; New York: Methuen, 1985.

\section{Jurnal}

Adventi Ferawati Sembiring, "Kedudukan Perempuan Dalam Hukum Waris Adat Pada Sistem Kekerabatan Patrilineal Di Lau Pakam, Kecamatan Mardingding, Kabupaten Karo, Provinsi Sumatra Utara”, Jurnal Hukum Dan Dinamika Masyarakat 15 (2), 2018

DOI : $\underline{10.36356 / \mathrm{hdm} . \mathrm{v} 15 \mathrm{i} 2.679}$

Eric Evonsus Simbolon dkk, "Peranan Dalihan Na Tolu Dalam Hukum Perkawinan Adat Batak Toba", Pactum Law Journal 1 (1), 2017.

Grecetinovitria Merliana Butar-Butar" "Eksistensi Perempuan Batak Toba Dalam Budaya Dan Agama”, Jurnal Pionir LPPM Universitas Asahan 6 (2), 2020. DOI : 10.36294/pionir.v6i2.1235

Harisan Boni Firmando, "Status dan Peranan Perempuan Setelah Berumah Tangga dalam Masyarakat Batak Toba di Tapanuli Utara (Analisis Sosiologis) Status and Role of Women After Married at Toba Batak Community in North Tapanuli (Sociological Analysis)", Jurnal Intervensi Sosial dan Pembangunan 2 (1), 2021. 
Helprida Nababan, "Kedudukan Anak Perempuan Pada Masyarakat Batak Toba Dalam Hukum Waris Adat Di Kota Pontianak", Jurnal Gloria Yuris 5 (3), 2017.

Indah Ahdiah, "Peran-Peran perempuan Dalam Masyarakat”, Jurnal Academica Fisip Untad 5 (2), 2013.

Mangihut Siregar, “Ketidaksetaraan Gender Dalam Dalihan Na Tolu”, Jurnal Studi Kultural 3, (1), 2017.

Pudji Astuti, Tri Marhaeni, "Ekofeminisme Dan Peran Perempuan Dalam Lingkungan", Indonesian Journal of Conservation 1 (1), 2012

Rismawati, "Perkawinan dan Pertukaran Batak Toba (Sebuah Tinjauan Strukturalisme Antropologi)", Jurnal Academica 3 (2), 2011.

Rouli Lastiurma Sinaga, "Kedudukan Anak Perempuan Dalam Hukum Waris Adat Pada Masyarakat Batak Di Kabupaten Aceh Tengah". JIM Bidang Hukum Keperdataan 1 (1), 2017.

Silvi Novita Nurman, "Keudukan Perempuan Minangkabau Dalam Perspektif Gender”, Jurnal Al-Aqidah 11 (1), 2019. DOI : 10.15548/ja.v11i1.911

\section{Artikel Lainnya}

Nasrany Nainy Romaini, "Posisi Perempuan Dalam Adat Dan Kebudayaan Masyarakat Batak Toba", Skripsi, 2001 